\title{
Retrospective analysis of metastatic behaviour of breast cancer subtypes
}

\author{
C. Dilara Savci-Heijink ${ }^{1}$ - Hans Halfwerk ${ }^{1}$ Gerrit K. J. Hooijer ${ }^{1}$ • \\ Hugo M. Horlings ${ }^{1} \cdot$ Jelle Wesseling $^{2} \cdot$ Marc J. van de Vijver $^{1}$
}

Received: 13 January 2015/Accepted: 16 March 2015/Published online: 29 March 2015

(C) The Author(s) 2015. This article is published with open access at Springerlink.com

\begin{abstract}
Among breast cancer patients who develop distant metastases, there is marked variability in the clinical course, including metastasis pattern. Here, we present a retrospective study of breast cancer patients who all developed distant metastases focusing on the association between breast cancer subtype and clinical course, including organspecific metastasis. Tissue microarrays (TMAs) were assembled and stained for ER, PR, HER2, EGFR, CK5/6, CK14, E-Cadherin, TP53 and Ki67 for 263 breast cancer patients with metastatic disease. Tumours were classified into ER+/HER2-/Ki67high, ER+/HER2-/Ki67low, $\mathrm{ER}+/ \mathrm{HER} 2+$, ER-/HER2+ and ER-/HER2- groups. Relevant data related to metastasis pattern, metastasis timeline, systemic treatment and survival were retrieved. Associations between site-specific relapse and patient/tumour characteristics were assessed with multivariate models using logistic regression. Median time for development of distant metastasis was 30 months (range $0-15.3$ years); $75.8 \%$ of the distance metastases developed in the first 5 years after treatment of the primary tumour. Patients with ER-/HER2 - tumours had a median overall survival of 27 months; those with HER2 + tumours of 52 months; those with ER+/HER2-/Ki67high of 76 months and those with ER+/HER2-/Ki67low of 79 months. Bone was the most common site for distant metastasis $(70.6 \%)$ followed by
\end{abstract}

C. Dilara Savci-Heijink

c.d.savciheijink@amc.uva.nl

$\triangle$ Marc J. van de Vijver

m.j.vandevijver@amc.uva.nl

1 Department of Pathology, Academic Medical Center, Meibergdreef 9, 1105 AZ Amsterdam, The Netherlands

2 Department of Pathology, The Netherlands Cancer Institute, 1066 CX Amsterdam, The Netherlands liver $(54.5 \%)$ and lung $(31.4 \%)$, respectively. Visceral metastasis was found in $76.8 \%$ of the patients. Patients with ER-/HER2 - tumours developed visceral metastases in $81 \%$ and bone metastases in $55.2 \%$; those with HER2+ tumours developed visceral metastases in $77.4 \%$ and bone metastases in $69.8 \%$; those with ER+/HER2-/Ki67high developed visceral metastases in $75.7 \%$ and bone metastases in $87.8 \%$ and those with ER+/HER2-/Ki67low developed visceral metastases in $76.9 \%$ and bone metastases in $73.1 \%$. In metastatic breast cancer patients, tumour subtypes are associated with survival and pattern of distant metastases. These associations are of help in choices for surveillance and therapy in individual patients.

Keywords Organotropism - Tumour · Pathology · Immunohistochemistry $\cdot$ Site-specific relapse

$\begin{array}{ll}\text { Abbreviations } \\ \text { TMA } & \text { Tissue microarray } \\ \text { ER } & \text { Oestrogen receptor } \\ \text { PR } & \text { Progesterone receptor } \\ \text { HER2 } & \text { Human epidermal growth factor receptor } 2 \\ \text { EGFR } & \text { Epidermal growth factor } \\ \text { CK } & \text { Cytokeratin } \\ \text { FSOM } & \text { First site of metastasis } \\ \text { MSS } & \text { Metastasis-specific survival } \\ \text { OS } & \text { Overall survival }\end{array}$

Introduction

Although the cure rate of breast cancer is increasing in the western world, breast cancer remains the leading cause of female cancer deaths [1]. Most breast cancer deaths are 
related to distant organ metastasis, which is considered to be essentially incurable. The development of metastatic breast cancer is a complex multi-step process manifesting with distinct patterns of distal organ involvement [2-6]. Using gene expression profiling studies, several molecular mechanisms associated with organ-specific metastasis patterns have been reported [4, 7-15]. Even though these gene expression signatures have already provided useful information in the characterization of novel molecular mediators of organ-specific metastasis, translation of these recently published data to clinical practice has not been accomplished. Moreover, the number of studies focusing on association of more conventional clinicopathologic findings to metastasis pattern is limited [3, 7, 16, 17].

The metastasis pattern of breast cancer varies by hormone receptor status. It has been shown that triple-negative tumours show increased incidence of visceral and cerebral distant metastasis, while hormone receptor-positive tumours have been shown to have a greater tendency to develop bone metastasis. HER2-positive tumours have been reported to metastasize to the brain more frequently than HER2-negative tumours [12, 16, 18-27].

Population-based studies suggest that the survival for metastatic breast cancer patients has been prolonged in recent years as a result of more effective systemic treatment [28-30]. However, patients with triple-negative breast cancer continue to have dismal outcome after the development of distant metastases [19, 22, 31-33] with a shorter median survival compared to hormone receptor and/or HER2-positive breast cancer [28].

To improve our understanding of the time course and pattern of distant metastases, a retrospective study was carried out using tissue microarrays of primary invasive breast carcinomas of patients who developed distant metastatic disease. Our objectives were to compare the clinicopathologic findings with metastatic behaviour of the breast tumours in terms of organ-specific metastasis and associated patient outcomes.

\section{Material and methods}

\section{Patients and tumour samples}

Patients with metastatic breast cancer diagnosed between 1983 and 2009 were identified from the archives of the Academic Medical Center and the Netherlands Cancer Institute (total $n=263$ ), and relevant clinical information was abstracted from their clinical charts. This study material was strictly handled after coding of the data according to national ethical guidelines of 'Code for Proper Secondary Use of Human Tissue' developed by Federation of Medical Societies (FMWV) in the Netherlands [34].
Therefore, the need for obtaining informed consent was waived by the Medical Ethical Committee of the Academic Medical Center.

Metastatic disease was defined as recurrence of breast cancer occurring beyond the confines of the ipsilateral breast, chest wall and regional lymph nodes. Metastatic site was classified as bone, lung, liver, pleura/peritoneum, brain, distant lymph nodes and other (including skin, spleen, ovary, eye and other organs). These individual metastasis sites were further used to separate patients in subgroups; for each metastatic site, it was assessed whether patients developed metastases during follow-up (ever versus never for each organ site); when patients developed metastases to any organ site, it was recorded whether this was the first metastasis or a metastasis arising after metastases to other organ site arose (first/not first); and it was recorded when a patient developed metastases to one organ site only (only/not only). The presence of multiple metastases was also carefully recorded at the time of diagnosis of the first metastases as well as after the complete follow-up. In instances where patients developed another distal organ involvement within less than 2 months after initial diagnosis of a metastasis, this was also considered as multiple organ metastases at first presentation.

Time from surgery to development of first metastasis, time from first metastasis to last event (metastasis-specific survival, MSS) and overall survival (OS) time for each patient were calculated. Last event date was recorded as most recent follow-up date for the patients who were alive and time of death for the others. Nineteen of the patients were lost to follow-up.

Furthermore, data on systemic treatment (chemotherapy, hormonal therapy, HER2-targeted therapy) used to treat primary and metastatic disease were collected for a subset of the patients ( $n=149$ and 124, respectively).

\section{Morphological features and immunophenotypic analysis}

From all tumours, hematoxylin-eosin-stained slides from paraffin-embedded tissues were evaluated and tumour type, histologic grade according to Elston and Ellis [35] and the presence of lymfangioinvasion were assessed. Tissue microarrays (TMAs) were constructed by a manual tissue arrayer (Beecher Instruments, Silver Spring, MD, USA) from the selected representative blocks $(n=263)$. Immunohistochemical staining for oestrogen receptor (ER) [clone SP1, Ventana], progesterone receptor (PR) [clone 1E2, Ventana], human epidermal growth factor receptor 2 (HER2) [clone SP3, Thermo Scientific], epidermal growth factor receptor (EGFR) [clone H11, Dako], Cytokeratin-5/6 (CK5/6) [clone D5/16 B4, Dako], Cytokeratin-14 (CK14) [clone LL002, Leica] E-Cadherin [clone HECD-1, 
Invitrogen], TP53 [clone DO-7 +BP53-12, Thermo Scientific] and Ki67 [clone SP6, Thermo Scientific] was performed using an automated slide preparation system (Benchmark XT, Ventana Medical Systems, Tucson Arizona, USA). On the same platform a silver in situ hybridisation (SISH) was performed with INFORM HER2 DNA probe obtained from Ventana Medical Systems. The signal detection for IHC was performed with a biotin-free ultraview universal DAB detection Kit (Ventana Medical Systems) and for SISH with an ultraview SISH detection kit (Ventana Medical Systems).

The immunohistochemistry results were scored independently by two pathologists (C.D.S-H and MJvdV). ER and $P R$ positivity were defined as nuclear staining in $10 \%$ or more of tumour cells. Scoring for HER2 immunohistochemistry and in situ hybridization was performed according to ASCO guidelines [36]. Briefly, HER2 staining was scored as $0,1+, 2+$ or $3+$; a score of $3+$ was considered to be HER2 positive and 0 or $1+$ HER2 negative and $2+$ scores were evaluated by silver enhanced in situ hybridization (SISH) to determine final HER2 status. For mono colour SISH, the number of nuclear spots was counted in 30 adjacent tumour cells and tumours with an average number of HER2 signals $\geq 6$ were considered as HER2 amplified; all other tumours were considered as HER2 non-amplified. Tumours were further grouped by ER/HER2 expression pattern as ERpositive/HER2-positive, ER-positive/HER2-negative, ERnegative/HER2-positive and ER-negative/HER2-negative tumours. ER-positive/HER2-negative tumours were further divided into two subgroups according to their Ki67 immunopositivity. For Ki-67 staining, the percentage of positively staining tumour cells was counted and a cut-off for low versus high of $13 \%$ was used according to the St Gallen consensus guidelines [37, 38]. Hormone receptor-negative group was also divided into 2 subgroups according to their so-called basal cell marker status. The hormone-negative tumours, which were positive for CK5/6 and/or CK14 and/or EGFR and/or C-kit, were considered to be basal-like tumours, whereas the others considered to be non-basal-like group of tumours [39, 40].

Samples were considered to be positive for TP53 if more than $50 \%$ of tumour cells showed positive staining in the nuclei. E-cadherin was scored as positive when there was any membranous staining. CK5/6, CK14, C-kit, E-cadherin and EGFR were scored as positive if $\geq 10 \%$ of the tumour cells showed staining.

\section{Statistical analysis}

Association between immunophenotypic findings and metastatic behaviour (including metastasis site and metastasis pattern) was assessed using either the Fisher Exact test (variable with two classes) or Chi-square test. To further explore this association, multivariate logistic regression analyses were applied to model the relationship between site-specific relapse and patient/tumour characteristics. All statistical tests were two sided and $p<0.05$ was considered to be statistically significant. Survival analyses were estimated by the Kaplan-Meier method and were compared using the log-rank test. Analyses were performed using SPSS Statistics for Windows (Release version 21.0; IBM Corp. 2012, Armond, NY, USA).

\section{Results}

\section{Clinicopathologic features}

For 263 patients treated for breast cancer who all developed distant metastases during follow-up, we have collected paraffin-embedded tumour tissue of the primary tumour; assessed the histopathological features and performed immunohistochemical staining on tissue microarrays (TMA's). Clinicopathologic data are shown in Table 1 . The mean age at diagnosis was 50 years (range 27-86). Median follow-up was 57 months for all patients (range 0.5-22.4 years) and 11.6 years (range 6.2-17.3 years) for patients $(n=14)$ who were alive at last follow-up. The majority of the tumours $(88.2 \%)$ were classified as invasive ductal carcinoma, and $90.9 \%$ of the tumours were grade 2 or 3 [35]. Tumour size varied from 0.5 to $9 \mathrm{~cm}$ with a mean size of $3.2 \mathrm{~cm}$.

Out of 149 patients with available adjuvant therapy data, $85(57 \%)$ patients received chemotherapy, whereas 61 $(40.9 \%)$ patients received hormonal therapy. More specifically $46.5 \%$ of patients with ER+ tumours were noted to receive hormonal therapy. Among 122 patients with available chemotherapy data for the metastatic disease, 50 patients received chemotherapy as first-line treatment after the development of metastatic disease, whereas 66 patients received hormonal therapy (40.7 and $50.7 \%$, respectively). Selective oestrogen receptor modulators were the most common (45.8\%) administered first-line hormonal therapy regimen, followed by aromatase inhibitors $(41.7 \%)$ and $\mathrm{LH}$ blockers $(46.8 \%)$. Only 14 patients received Herceptin therapy for treating metastatic disease.

Results of immunohistochemical staining can be seen in Table 2. When grouped into subtypes according to ER/ HER2 expression, $27.6 \%$ were ER-/HER2-, $24.8 \%$ were HER2 positive and $47.6 \%$ were ER+/HER2-. Of ER+/HER2- tumours, $93.7 \%$ were Ki67 high and $6.3 \%$ were Ki67 low, $31.8 \%$ were TP53 positive; $4.1 \%$ were EGFR positive; $9.4 \%$ were CK14 positive and $15.4 \%$ were CK5/6 positive. $61.1 \%$ of the ER-/HER2- tumours were positive for one of the so-called basal cell markers (CK5/6, CK14, EGFR or C-kit). Of note, within the hormone receptor-negative group, no significant difference 
Table 1 Clinical and pathological characteristics of metastatic breast cancer patients

\begin{tabular}{lll}
\hline & $N$ & $\%$ \\
\hline
\end{tabular}

Age at diagnosis, years

$\begin{array}{lll}<50 & 146 & 55.5 \\ >50 & 117 & 44.5\end{array}$

Lymph node status

Negative 54

1-3 Positive

$>3$ Positive

51

Histology

Ductal

Lobular

Other

Tumour grade

1

2

3

20

11

23

134

96

Tumour size

$0-2 \mathrm{~cm}$

$2-5 \mathrm{~cm}$

$>5 \mathrm{~cm}$

Tumour subtype

ER(-) HER2(-)

ER(+) HER2(-) Ki67high

ER(+) HER2(-) Ki67low

27

$\mathrm{ER}(+) \operatorname{HER} 2(+)$

28

$\operatorname{ER}(-) \operatorname{HER} 2(+)$

25

Time to distant metastasis ${ }^{\mathrm{a}}$

$\begin{array}{lr}\text { Early } & 194 \\ \text { Late } & 62\end{array}$

Multiple metastasis sites at first presentation

No

160

Yes

Multiple metastasis sites during follow-up

No

Yes

205

$C T$ chemotherapy, $H T$ hormonal therapy, $E R$ oestrogen receptor, $P R$ progesterone receptor; HER2 human epidermal growth factor receptor

${ }^{\text {a }}$ Cut-off point 5 years

was found between the tumours with and without basal-like markers regarding clinicopathological characteristics, metastatic behaviour and survival outcomes. Therefore, we have chosen to proceed with hormone receptor-negative group as one group.

Findings of immunohistochemical staining for TP53, CK5/6, CK14, EGFR, c-kit and Ki67 in hormone receptornegative tumours are displayed in Table $3.10 .4 \%$ of tumours were E-cadherin negative; $54.2 \%$ of these were classified as invasive lobular carcinomas.
Table 2 Results of immunohistochemical staining in the primary tumours

\begin{tabular}{|c|c|c|}
\hline & $N$ & $\% *$ \\
\hline \multicolumn{3}{|l|}{ ER } \\
\hline Negative & 84 & 34.1 \\
\hline Positive & 162 & 65.9 \\
\hline \multicolumn{3}{|l|}{ PR } \\
\hline Negative & 93 & 37.1 \\
\hline Positive & 158 & 62.9 \\
\hline \multicolumn{3}{|l|}{ HER2 } \\
\hline Negative & 199 & 78.3 \\
\hline Positive & 55 & 21.7 \\
\hline \multicolumn{3}{|l|}{ E-cadherin } \\
\hline Negative & 24 & 10.4 \\
\hline Positive & 206 & 89.6 \\
\hline \multicolumn{3}{|l|}{ CK5/6 } \\
\hline Negative & 193 & 84.6 \\
\hline Positive & 35 & 15.4 \\
\hline \multicolumn{3}{|l|}{ CK14 } \\
\hline Negative & 213 & 90.6 \\
\hline Positive & 22 & 9.4 \\
\hline \multicolumn{3}{|l|}{ EGFR } \\
\hline Negative & 232 & 95.9 \\
\hline Positive & 10 & 4.1 \\
\hline \multicolumn{3}{|l|}{ TP53 } \\
\hline Negative & 163 & 69.1 \\
\hline Positive & 73 & 30.9 \\
\hline \multicolumn{3}{|l|}{ c-kit } \\
\hline Negative & 233 & 96.7 \\
\hline Positive & 8 & 3.3 \\
\hline \multicolumn{3}{|l|}{ Ki67 } \\
\hline Low & 37 & 19.3 \\
\hline High & 155 & 80.7 \\
\hline
\end{tabular}

$E R$ oestrogen receptor, $P R$ progesterone receptor, $H E R 2$ human epidermal growth factor receptor, $C K$ cytokeratin, $E G F R$ epidermal growth factor receptor

* Valid percentages

\section{Time to distant metastasis}

Median time to develop metastasis was 30 months (range $0-15.3$ years) and median time from metastasis to death was 19 months and to last follow-up for patients alive was 64 months. Using the cut-off point of 5 years, $75.8 \%$ of the tumours were recorded as early metastasizing tumours. In Table 4, the association between histologic and immunohistochemical variables and early versus late metastasis is shown.

As can be seen, ER-/HER2 - and ER-/HER2+ tumours metastasized earlier than other subgroups of tumours ( $p=0.003$ ). Almost $90 \%$ of hormone-negative breast cancer patients developed distant metastases early versus 
Table 3 Results of immunohistochemical staining in ER-/HER2tumours

\begin{tabular}{lrr}
\hline & $N$ & $\%{ }^{*}$ \\
\hline TP53 & 24 & \\
Negative & 33 & 52.1 \\
Positive & & 57.9 \\
CK5/6 & 28 & 52.8 \\
Negative & 25 & 47.2 \\
Positive & & \\
CK14 & 39 & 70.9 \\
Negative & 16 & 29.1 \\
Positive & & \\
EGFR & 47 & 82.5 \\
Negative & 10 & 17.5 \\
Positive & & \\
c-kit & 52 & 91.2 \\
Negative & 5.8 \\
Positive & 5 & \\
Ki67 & & 4.5 \\
Low & 2 & 95.5 \\
High & 42 & \\
\hline CK cytokertin & &
\end{tabular}

$C K$ cytokeratin, $E G F R$ epidermal growth factor receptor

* Valid percentages

$66 \%$ of ER+/HER2-; within ER+/HER2 - group, there was no significant difference between Ki67 high $(66.7 \%)$ and Ki67 low (65.4\%) tumours $(p=0.54)$.

\section{Survival after development of distant metastases}

Figure 1 shows that overall survival and survival after the detection of distant metastasis for patients who developed visceral metastases $(n=198)$ are worse than for those who did not develop visceral metastases $(p=0.073$ and 0.009 , respectively). Figure 2 shows overall survival and survival after the detection of distant metastasis for the subgroups of patients defined by ER and HER 2 status of the primary tumour.

Table 5 demonstrates the differences of time to develop metastasis and survival time after development of metastatic disease in various subgroups. As can be seen, patients with ER-/HER2 - tumours had a median survival of 10 months after the detection of distant metastasis, whereas ER-/ HER2+ tumours had median survival of 19 months $(p=0.020)$. ER $+/$ HER2 $-($ Ki67 high as well as Ki67 low groups) and ER+/HER2+ tumours had a median survival time of 25 and 24 months, respectively ( $p=0.75$ ).

\section{Site of distant metastasis}

Detailed information about metastatic behaviour was available for 256 patients; $11(4.3 \%)$ patients presented
Table 4 Correlation between tumour characteristics and time to distant metastasis

\begin{tabular}{|c|c|c|c|c|c|}
\hline \multirow[t]{3}{*}{ Characteristics } & \multicolumn{5}{|c|}{ Metastasis timeline } \\
\hline & \multicolumn{2}{|c|}{$<5$ years } & \multicolumn{2}{|c|}{$>5$ years } & \multirow[t]{2}{*}{$p$} \\
\hline & $N$ & $\%$ & $N$ & $\%$ & \\
\hline \multicolumn{6}{|l|}{ Tumour size } \\
\hline$<2 \mathrm{~cm}$ & 37 & 21.8 & 27 & 42.9 & \multirow[t]{2}{*}{0.001} \\
\hline$\geq 2$ & 133 & 78.2 & 36 & 57.1 & \\
\hline \multicolumn{6}{|l|}{ Tumour grade } \\
\hline 1 & 17 & 8.5 & 7 & 10.6 & \multirow{3}{*}{0.056} \\
\hline 2 & 99 & 49.3 & 42 & 63.6 & \\
\hline 3 & 85 & 42.3 & 17 & 25.8 & \\
\hline \multicolumn{6}{|l|}{ ER } \\
\hline Negative & 73 & 37.4 & 10 & 15.2 & \multirow[b]{2}{*}{0.001} \\
\hline Positive & 122 & 62.6 & 56 & 84.8 & \\
\hline \multicolumn{6}{|l|}{ PR } \\
\hline Negative & 83 & 41.9 & 12 & 17.6 & \multirow[b]{2}{*}{$<0.001$} \\
\hline Positive & 115 & 58.1 & 56 & 82.4 & \\
\hline \multicolumn{6}{|l|}{ Tumour subtype } \\
\hline $\operatorname{ER}(-) \operatorname{HER} 2(-)$ & 52 & 30.8 & 7 & 13.5 & \multirow{5}{*}{0.003} \\
\hline ER(+) HER2(-) Ki67high & 50 & 29.6 & 25 & 48.1 & \\
\hline ER(+) HER2(-) Ki67low & 17 & 10.1 & 9 & 17.3 & \\
\hline $\mathrm{ER}(+) \operatorname{HER} 2(+)$ & 29 & 17.2 & 8 & 15.4 & \\
\hline $\operatorname{ER}(-) \operatorname{HER} 2(+)$ & 21 & 12.4 & 3 & 5.8 & \\
\hline
\end{tabular}

$E R$ oestrogen receptor, $P R$ progesterone receptor, HER2 human epidermal growth factor receptor

with multiple metastasis simultaneously, while 205 (80.4\%) developed multiple metastases during the course of follow-up. Bone was the most common site for metastasis $(70.6 \%)$ followed by liver $(54.5 \%)$ and lung (31.4\%), respectively. Visceral (liver, lung and brain) metastases were found in $77.6 \%$ of the patients.

Twenty-five $(9.8 \%)$ of the patients developed only bone metastasis and $29(11.4 \%)$ of the patients developed only visceral metastasis during the course of the disease. Among these patients, median time to develop bone metastasis and visceral metastasis differed and was 40 and 23 months, respectively.

Multivariate analyses further revealed that patients who developed visceral metastasis had a higher prevalence of multiple metastases during follow-up $(p=<0.001)$.

The metastasis pattern was similar for patients who received adjuvant systemic therapy compared to patients who did not undergo adjuvant systemic treatment.

Along with $81.3 \%$ of ER+ tumours, $88 \%$ of ER+l HER2 - Ki67 high tumours noted to have bone metastasis. Contrarily, hormone-negative (ER-/HER2-) tumours were associated with visceral organ metastasis, yet composing $55 \%$ of the tumours with only visceral metastasis. 


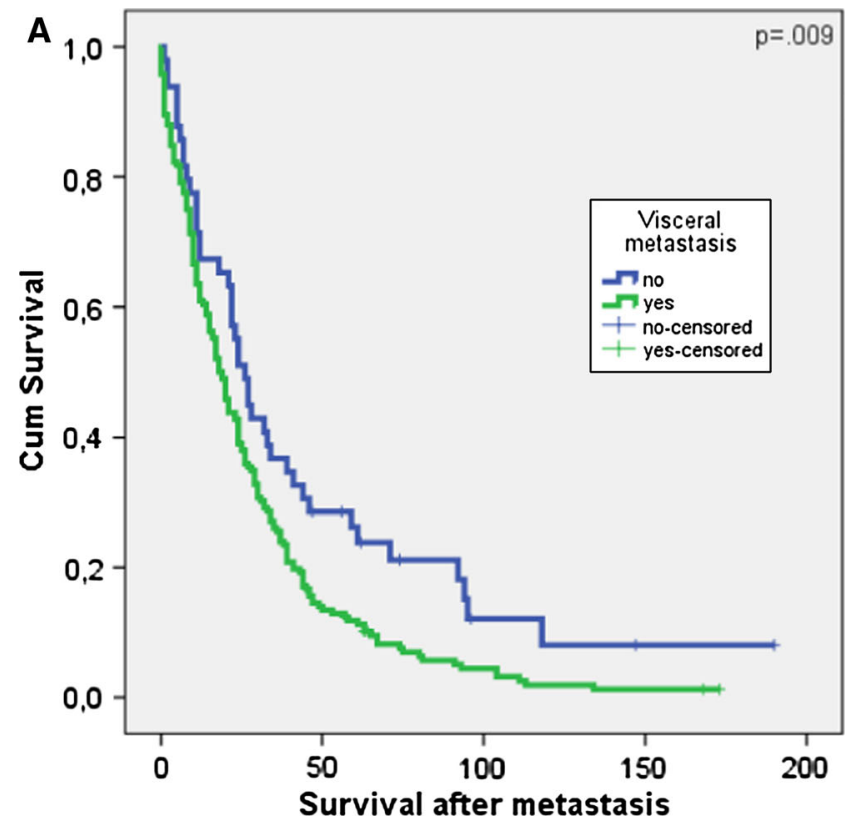

Fig. 1 Metastasis-specific (a) and overall (b) survival curves of breast cancer patients with and without visceral metastasis. KaplanMeier plots of patients show that tumours with visceral metastasis had worse survival outcomes than the tumours without visceral organ

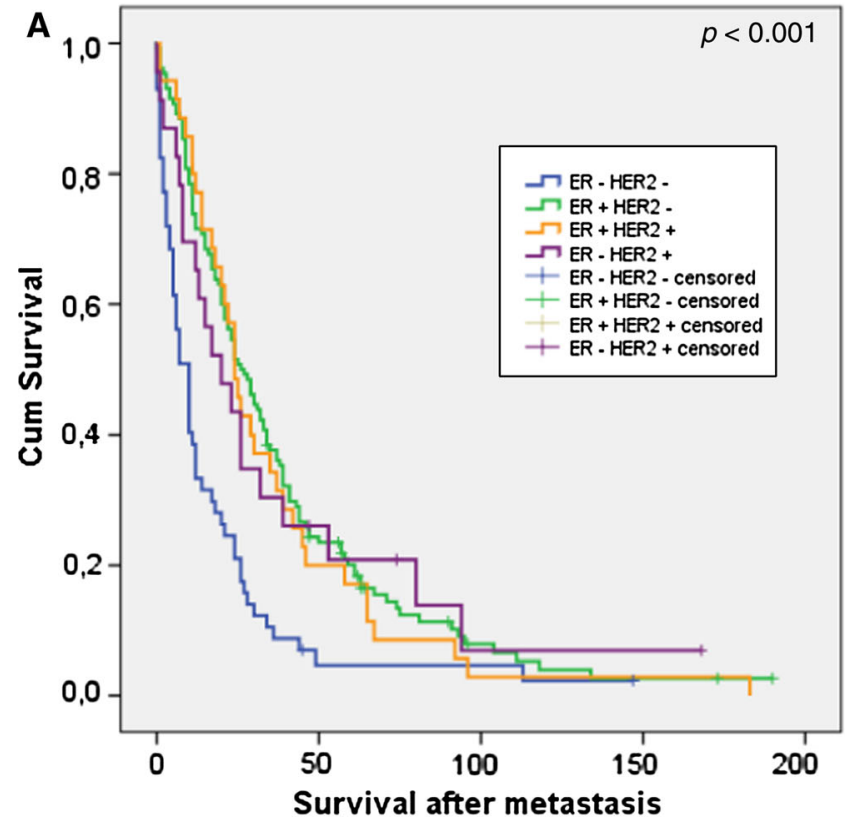

Fig. 2 Metastasis-specific (a) and overall (b) survival curves of breast cancer patients according to tumour subtypes. $E R$ oestrogen receptor, $P R$ progesterone receptor, $H E R 2$ human epidermal growth factor receptor type 2. Kaplan-Meier plots of patients show that ER-/ HER2 - had worse survival outcomes compared to other tumour

ER status of the tumour was significantly positively correlated to bone metastasis in the univariate as well as in the multivariate analyses. Several immunohistochemical

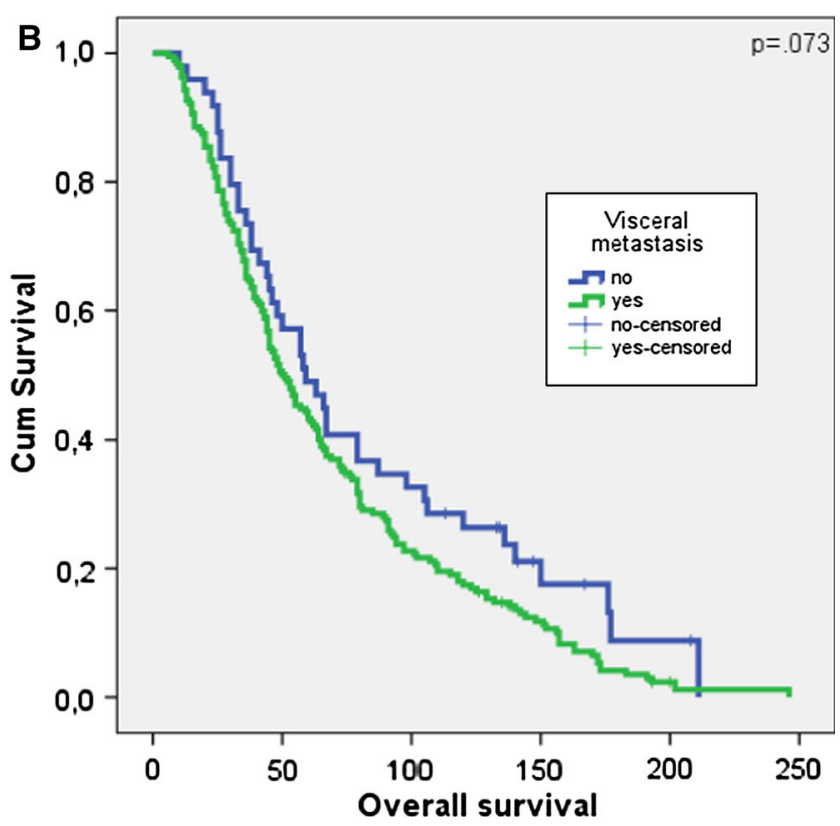

metastasis. Patients who had visceral metastasis had shorter survival time from detection of metastasis to last event and from the initial diagnosis of the disease to last event $(p=0.009$ and 0.073 , respectively)

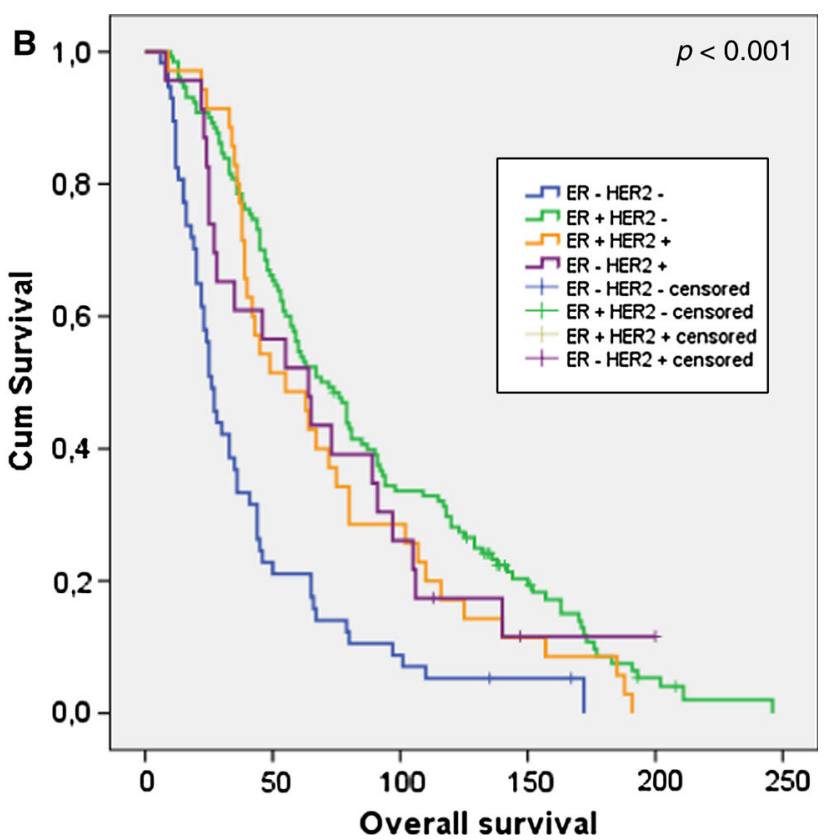

subtypes. Patients with hormone receptor-negative (ER-/HER2-) tumours had shorter survival time from detection of metastatic disease to last event and from the initial diagnosis of the disease to last event $(p<0.001)$

markers, such as E-Cadherin and Cytokeratin 14, were found to be correlated to visceral metastasis $(p=0.013$ and 0.018 ). E-cadherin was found to be positive in primary 
Table 5 Tumour characteristics and interval to metastasis and last event

\begin{tabular}{|c|c|c|c|c|c|c|}
\hline & \multicolumn{2}{|c|}{$\begin{array}{l}\text { Interval between surgery } \\
\text { and metastasis, months }\end{array}$} & \multicolumn{2}{|c|}{$\begin{array}{l}\text { Interval between metastasis } \\
\text { and last event, months }\end{array}$} & \multicolumn{2}{|c|}{ Overall survival } \\
\hline & Mean & Median & Mean & Median & Mean & Median \\
\hline \multicolumn{7}{|l|}{ Tumour subtype } \\
\hline $\operatorname{ER}(-) \operatorname{HER} 2(-)$ & 25 & 15 & 17 & 10 & 41 & 27 \\
\hline ER(+) HER2(-) Ki67high & 51 & 37 & 36 & 25 & 86 & 76 \\
\hline ER(+) HER2(-) Ki67low & 54 & 45 & 39 & 25 & 93 & 79 \\
\hline $\mathrm{ER}(+) \operatorname{HER} 2(+)$ & 40 & 33 & 41 & 25 & 79 & 59 \\
\hline $\mathrm{ER}(-) \operatorname{HER} 2(+)$ & 36 & 22 & 33 & 19 & 69 & 60 \\
\hline$p$ value & $<0.001$ & & 0.002 & & 0.020 & \\
\hline
\end{tabular}

$E R$ oestrogen receptor, $P R$ progesterone receptor, HER2 human epidermal growth factor receptor

tumours of patients who developed visceral organ metastasis and the ones with visceral metastasis as initial site of metastasis ( $p=0.028$ and 0.040). TP53-positive tumours developed brain metastasis with a rate of $38 \%$, as opposed to $21.2 \%$ in TP53-negative ones ( $p=0.007)$.

\section{Discussion}

Breast cancer is a heterogeneous disease and this is also reflected in the clinical patterns of the development of distant metastases. There is marked variability in the time interval between treatment of the primary tumour and the occurrence of distant metastases; in the organs involved with distant metastases and in the response to systemic treatment in patients with metastatic breast cancer. The concept of organotropism compasses the non-random distinct organ involvement of different cancer types as well as within a given type of cancer, which usually implies a more subtle intrinsic heterogeneity among organotropic cancer cells [4]. Along with the conventional metastatic model of "anatomical/mechanical" hypothesis, Paget's "seed and soil" hypothesis [41] is a widely accepted model for site-specific metastasis. Stephen Paget' s century old theory that proposed the organ-preference patterns of tumour metastasis is the product of favourable interactions between metastatic tumour cells (the "seed") and their organ microenvironment (the "soil") was confirmed by clinical and experimental research [4, 41-43]. Better understanding of this complex interaction between two compartments and consequently the mechanisms that lie beneath the site-specific metastasis may improve the clinical management, including developing novel therapeutic options, for metastatic disease.

Despite the increasing tendency to classify breast tumours into molecular subtypes based on gene expression profiles first described by Perou et al. [33], immunophenotypic characteristics of the tumour also remain an important cornerstone of defining subgroups of the disease. In the current study, we investigated the presence of sitespecific metastasis and concomitant characteristics of the metastatic disease in a retrospective series of 263 breast cancer patients, focusing on the immunophenotypic features of the primary tumour.

Together with clinical observations, recent comprehensive molecular studies unveiled the considerable differences between ER-positive and ER-negative tumours. It has also been shown that ER status has a time-varying prognostic effect mainly pronounced in the early follow-up period [4448]. ER-positive tumours are known for their tendency to relapse later with higher rate of bone recurrences than their ER-negative counterparts. In agreement with published literature, our data clearly indicate the close relation between ER-positive tumours and metastasis-specific survival and bone metastasis [18, 45, 46, 49]. In addition to confirming the well-established prognostic markers in breast cancer, this study was also able to verify that ER status is also an important factor for bone-only and bone-first metastasis. Likewise, in agreement with previously published data, ERnegative tumours showed a higher proportion of patients with visceral metastases [18, 20, 44, 45, 50]. HER2-positive tumours have been found as a risk factor for cerebral metastasis development $(5,12,13,19,22,24,27,29,32,33$, $52,55)$. However, in this study, HER2 positivity was not identified as a strong predictive factor for site-specific metastasis and early metastatic disease; of note, in our study, we did not find an association between HER2-positive status and brain metastasis. The fact that almost none of the patients in our study received adjuvant HER2-targeted therapy may play a role in the absence of a correlation between HER2 status and brain metastases (although we could not retrieve data on adjuvant systemic therapy for all patients, we know that HER2-targeted therapy was not yet available as adjuvant therapy during a large part of the period in which patients were treated).

A recent cohort study demonstrated that hormone receptor $(\mathrm{HR})+/ \mathrm{HER} 2+$ subtype was associated with the 
best prognosis after diagnosis of metastatic disease, with a median survival of 34.4 months even better than $\mathrm{HR}+$ / HER2 - subgroup [51]. This subgroup was followed by HR+/HER2-, HR-/HER2+ and hormone receptornegative tumours. In our study, regardless of their HER2 status, hormone receptor-positive tumours had better survival after the diagnosis of distant metastasis. Similar to Lobbezoo et al., ER-/HER2 + tumours had better survival than hormone receptor-negative tumours. Improved survival rates of HER2 + tumours have already been reported [28, 29, 52]. Even though our study includes patients before the implementation of HER2-targeted therapy for metastatic disease, our results are comparable to this recent cohort study. Additionally, further subgrouping of ER+/ HER2 - tumours according to their Ki67 status revealed that only minority $(6.3 \%)$ of these tumours had low Ki67 status. Within this group of tumours, there was also no significance regarding metastasis pattern. This result may suggest that if once metastatic event occurs, prognostic relevance of $\mathrm{Ki} 67$ might be limited.

Our analyses indicate the noticeable distinction between breast tumours with visceral metastasis and the ones without visceral metastasis. Additional to the remarkably shorter overall survival and metastasis-specific survival compared to the tumours without visceral metastasis, higher frequency of developing multiple metastasis during the course of disease, make this subgroup of tumours challenging and therefore worth to be recognized [49, 53]. Several immunohistochemical markers are known to be associated with hormone receptor-negative breast tumours especially the ones with basal-like features. It is also claimed that triplenegative status cannot be used as a surrogate for the basal cell phenotype [54-56]. In our study, we showed that a group of frequently registered immunohistochemistry markers such as CK 5/6, CK 14 and EGFR were related to the hormone receptor-negative subgroup ( $p<0.001$ ), while c-kit was not found to be related to this subgroup of tumours $(p=0.098)$. Further analyses within this group revealed no significant difference between basal-like group and non-basal-like group in relation to metastatic behaviour and survival outcomes. Based on gene expression profiling studies, Lehmann et al. showed that this aggressive type of breast cancer can be divided into seven subtypes as basal-like 1, basal-like2, immunomodulatory, mesenchymal-like, mesenchymal stemlike, luminal androgen receptor and unstable. They also showed that independent analysis of five datasets based on triple-negative tumours identified by immunohistochemical staining had similar clustering [57]. In conjunction with this information, it is indicated that hormone receptor-negative group contains heterogeneous group of tumours with distinct phenotypes. We believe that further studies are indicated to explore the role of immunohistochemistry to portray these heterogeneous subgroups.
The role of E-cadherin in metastatic potential of the tumours has already been a topic of interest. The absence of E-cadherin expression as a result of genetic alterations in the E-cadherin gene is observed in the majority of lobular carcinomas. Reduced expression of E-cadherin has been reported in breast carcinoma cases with a frequency ranging from 45 to $63 \%$ of cases [58-60]. Several studies showed a higher metastatic potential for tumours with reduced E-cadherin expression [58, 61-65], whereas others were not able to prove such a relation [66, 67]. Interestingly, in the current study, we showed that immunostaining of E-cadherin was positively correlated with developing visceral metastases, also with developing visceral metastasis as first site of metastasis.

It has been shown that tumours with TP53 gene mutations are associated with brain metastases. [27, 68, 69]. Recently, Lo et al. have demonstrated that mutation of TP53 is the most common genetic change identified in brain metastases from breast cancer. They identified that $87 \%$ of CNS metastatic lesions in their study contained TP53 mutations compared to 25-34\% mutations in all breast cancers. [70]. Consistent with the previous reports, we showed that TP53 immunopositivity is significantly associated with subsequent brain metastasis. The cohort of patients in our study was treated between 1983 and 2009; the median size of the primary tumours was $3.2 \mathrm{~cm}$. It may well be that metastatic patterns will differ for patients who were treated more recently and for patients who presented with smaller tumours. It will therefore be of interest to perform a similar study to the one presented here in the future for a cohort of more recently treated patients.

\section{Conclusions}

This study demonstrates that subtypes of breast cancer mainly defined by ER, PR and HER2 and are strongly related to the metastasis pattern, in terms of site-specific relapse, early/late metastasis and survival outcomes. Hormone receptor-positive tumours have tendency to develop bone metastasis and they have better survival outcomes compared to hormone receptor-negative tumours with a tendency of developing visceral metastasis. HER2 status was not associated with pattern of distant metastases; in agreement with previous reports, P53-positive tumours were more likely to metastasize to the brain than P53negative tumours. In addition, we show that tumours that develop visceral metastasis have worse prognosis than the ones without visceral metastasis and immunostaining for E-cadherin and cytokeratin 14 can be of help to identify such tumours. These associations are of help in choices for surveillance and therapy in individual patients. 
Acknowledgments This research was supported by the Center for Translational Molecular Medicine (BreastCARE).

Compliance with ethical standards This study material was strictly handled after coding of the data according to national ethical guidelines of 'Code for Proper Secondary Use of Human Tissue' developed by Federation of Medical Societies (FMWV) in the Netherlands [34]. Therefore, the need for obtaining informed consent was waived by the Medical Ethical Committee of the Academic Medical Center.

Conflict of interest The authors declare that they have no conflict of interest.

Open Access This article is distributed under the terms of the Creative Commons Attribution Noncommercial License which permits any noncommercial use, distribution, and reproduction in any medium, provided the original author(s) and the source are credited.

\section{References}

1. Malvezzi M, Bertuccio P, Levi F, La VC, Negri E (2012) European cancer mortality predictions for the year 2012. Ann Oncol 23(4):1044-1052. doi:10.1093/annonc/mds024

2. Lorusso G, Ruegg C (2012) New insights into the mechanisms of organ-specific breast cancer metastasis. Semin Cancer Biol 22(3):226-233. doi:10.1016/j.semcancer.2012.03.007

3. St RP, Madan R, Tawfik OW, Damjanov I, Fan F (2012) Organotropism and prognostic marker discordance in distant metastases of breast carcinoma: fact or fiction? A clinicopathologic analysis. Hum Pathol 43(3):398-404. doi:10.1016/j.hum path.2011.05.009

4. Lu X, Kang Y (2007) Organotropism of breast cancer metastasis. J Mammary Gland Biol Neoplasia 12(2-3):153-162. doi:10. 1007/s10911-007-9047-3

5. Chiang AC, Massague J (2008) Molecular basis of metastasis. N Engl J Med 359(26):2814-2823. doi:10.1056/NEJMra0805239

6. Chambers AF, Groom AC, MacDonald IC (2002) Dissemination and growth of cancer cells in metastatic sites. Nat Rev Cancer 2(8):563-572. doi:10.1038/nrc865

7. Altundag K, Bondy ML, Mirza NQ, Kau SW, Broglio K, Hortobagyi GN, Rivera E (2007) Clinicopathologic characteristics and prognostic factors in 420 metastatic breast cancer patients with central nervous system metastasis. Cancer 110(12):2640-2647. doi:10.1002/cncr.23088

8. Bos PD, Zhang XH, Nadal C, Shu W, Gomis RR, Nguyen DX, Minn AJ, van de Vijver MJ, Gerald WL, Foekens JA, Massague J (2009) Genes that mediate breast cancer metastasis to the brain. Nature 459(7249):1005-1009. doi:10.1038/nature08021

9. Harrell JC, Prat A, Parker JS, Fan C, He X, Carey L, Anders C, Ewend M, Perou CM (2012) Genomic analysis identifies unique signatures predictive of brain, lung, and liver relapse. Breast Cancer Res Treat 132(2):523-535. doi:10.1007/s10549-011-1619-7

10. Landemaine T, Jackson A, Bellahcene A, Rucci N, Sin S, Abad BM, Sierra A, Boudinet A, Guinebretiere JM, Ricevuto E, Nogues C, Briffod M, Bieche I, Cherel P, Garcia T, Castronovo V, Teti A, Lidereau R, Driouch K (2008) A six-gene signature predicting breast cancer lung metastasis. Cancer Res 68(15):6092-6099. doi:10.1158/0008-5472.CAN-08-0436

11. Paik S, Shak S, Tang G, Kim C, Baker J, Cronin M, Baehner FL, Walker MG, Watson D, Park T, Hiller W, Fisher ER, Wickerham DL, Bryant J, Wolmark N (2004) A multigene assay to predict recurrence of tamoxifen-treated, node-negative breast cancer. N Engl J Med 351(27):2817-2826. doi:10.1056/NEJMoa041588
12. Slimane K, Andre F, Delaloge S, Dunant A, Perez A, Grenier J, Massard C, Spielmann M (2004) Risk factors for brain relapse in patients with metastatic breast cancer. Ann Oncol 15(11):1640-1644. doi:10.1093/annonc/mdh432

13. van de Vijver MJ, He YD, van't Veer LJ, Dai H, Hart AA, Voskuil DW, Schreiber GJ, Peterse JL, Roberts C, Marton MJ, Parrish M, Atsma D, Witteveen A, Glas A, Delahaye L, van der Velde T, Bartelink H, Rodenhuis S, Rutgers ET, Friend SH, Bernards R (2002) A gene-expression signature as a predictor of survival in breast cancer. N Engl J Med 347(25):1999-2009. doi:10.1056/NEJMoa021967

14. Wang Y, Klijn JG, Zhang Y, Sieuwerts AM, Look MP, Yang F, Talantov D, Timmermans M, Meijer-van Gelder ME, Yu J, Jatkoe T, Berns EM, Atkins D, Foekens JA (2005) Gene-expression profiles to predict distant metastasis of lymph-node-negative primary breast cancer. Lancet 365(9460):671-679. doi:10.1016/ S0140-6736(05)17947-1

15. Zhang XH, Wang Q, Gerald W, Hudis CA, Norton L, Smid M, Foekens JA, Massague J (2009) Latent bone metastasis in breast cancer tied to Src-dependent survival signals. Cancer Cell 16(1):67-78. doi:10.1016/j.ccr.2009.05.017

16. Koo JS, Jung W, Jeong J (2010) Metastatic breast cancer shows different immunohistochemical phenotype according to metastatic site. Tumori 96(3):424-432

17. Lin Y, Yin W, Yan T, Zhou L, Di G, Wu J, Shen Z, Shao Z, Lu J (2009) Site-specific relapse pattern of the triple negative tumors in Chinese breast cancer patients. BMC Cancer 9:342. doi:10. 1186/1471-2407-9-342

18. Campbell FC, Blamey RW, Elston CW, Nicholson RI, Griffiths K, Haybittle JL (1981) Oestrogen-receptor status and sites of metastasis in breast cancer. Br J Cancer 44(3):456-459

19. Dent R, Trudeau M, Pritchard KI, Hanna WM, Kahn HK, Sawka CA, Lickley LA, Rawlinson E, Sun P, Narod SA (2007) Triplenegative breast cancer: clinical features and patterns of recurrence. Clin Cancer Res 13(15 Pt 1):4429-4434. doi:10.1158/ 1078-0432.CCR-06-3045

20. Dent R, Hanna WM, Trudeau M, Rawlinson E, Sun P, Narod SA (2009) Pattern of metastatic spread in triple-negative breast cancer. Breast Cancer Res Treat 115(2):423-428. doi:10.1007/ s10549-008-0086-2

21. Fuqua SA (2001) The role of estrogen receptors in breast cancer metastasis. J Mammary Gland Biol Neoplasia 6(4):407-417

22. Haffty BG, Yang Q, Reiss M, Kearney T, Higgins SA, Weidhaas J, Harris L, Hait W, Toppmeyer D (2006) Locoregional relapse and distant metastasis in conservatively managed triple negative early-stage breast cancer. J Clin Oncol 24(36):5652-5657. doi:10. 1200/JCO.2006.06.5664

23. Heitz F, Harter P, Lueck HJ, Fissler-Eckhoff A, Lorenz-Salehi F, Scheil-Bertram S, Traut A, du BA (2009) Triple-negative and HER2-overexpressing breast cancers exhibit an elevated risk and an earlier occurrence of cerebral metastases. Eur J Cancer 45(16):2792-2798. doi:10.1016/j.ejca.2009.06.027

24. Kennecke H, Yerushalmi R, Woods R, Cheang MC, Voduc D, Speers CH, Nielsen TO, Gelmon K (2010) Metastatic behavior of breast cancer subtypes. J Clin Oncol 28(20):3271-3277. doi:10. 1200/JCO.2009.25.9820

25. Largillier R, Ferrero JM, Doyen J, Barriere J, Namer M, Mari V, Courdi A, Hannoun-Levi JM, Ettore F, Birtwisle-Peyrottes I, BaluMaestro C, Marcy PY, Raoust I, Lallement M, Chamorey E (2008) Prognostic factors in 1038 women with metastatic breast cancer. Ann Oncol 19(12):2012-2019. doi:10.1093/annonc/mdn424

26. Lin NU, Claus E, Sohl J, Razzak AR, Arnaout A, Winer EP (2008) Sites of distant recurrence and clinical outcomes in patients with metastatic triple-negative breast cancer: high incidence of central nervous system metastases. Cancer 113(10):2638-2645. doi:10.1002/cncr.23930 
27. Tham YL, Sexton K, Kramer R, Hilsenbeck S, Elledge R (2006) Primary breast cancer phenotypes associated with propensity for central nervous system metastases. Cancer 107(4):696-704. doi:10.1002/cncr.22041

28. Chia SK, Speers CH, D'yachkova Y, Kang A, Malfair-Taylor S, Barnett J, Coldman A, Gelmon KA, O'reilly SE, Olivotto IA (2007) The impact of new chemotherapeutic and hormone agents on survival in a population-based cohort of women with metastatic breast cancer. Cancer 110(5):973-979. doi:10.1002/ cncr.22867

29. Dawood S, Broglio K, Gonzalez-Angulo AM, Buzdar AU, Hortobagyi GN, Giordano SH (2008) Trends in survival over the past two decades among white and black patients with newly diagnosed stage IV breast cancer. J Clin Oncol 26(30):4891-4898. doi:10.1200/JCO.2007.14.1168

30. Giordano SH, Buzdar AU, Smith TL, Kau SW, Yang Y, Hortobagyi GN (2004) Is breast cancer survival improving? Cancer 100(1):44-52. doi:10.1002/cncr.11859

31. Bauer KR, Brown M, Cress RD, Parise CA, Caggiano V (2007) Descriptive analysis of estrogen receptor (ER)-negative, progesterone receptor (PR)-negative, and HER2-negative invasive breast cancer, the so-called triple-negative phenotype: a population-based study from the California cancer Registry. Cancer 109(9):1721-1728. doi:10.1002/cncr.22618

32. Foulkes WD, Brunet JS, Stefansson IM, Straume O, Chappuis PO, Begin LR, Hamel N, Goffin JR, Wong N, Trudel M, Kapusta L, Porter P, Akslen LA (2004) The prognostic implication of the basal-like (cyclin E high/p27 low/p53+/glomeruloid-microvascular-proliferation+) phenotype of BRCA1-related breast cancer. Cancer Res 64(3):830-835

33. Perou CM, Sorlie T, Eisen MB, van de Rijn M, Jeffrey SS, Rees CA, Pollack JR, Ross DT, Johnsen H, Akslen LA, Fluge O, Pergamenschikov A, Williams C, Zhu SX, Lonning PE, Borresen-Dale AL, Brown PO, Botstein D (2000) Molecular portraits of human breast tumours. Nature 406(6797):747-752. doi:10. $1038 / 35021093$

34. Vermeulen E, Geesink I, Schmidt MK, Steegers C, Verhue D, Brom FW, Aaronson NK, van Leeuwen FE (2009) Secondary use of human tissue: consent and better information required. Ned Tijdschr Geneeskd 153:A948

35. Elston CW, Ellis IO (2002) Pathological prognostic factors in breast cancer. I. The value of histological grade in breast cancer: experience from a large study with long-term follow-up. Histopathology 1991; 19:403-410. Histopathology 41(3A):151-152, discussion

36. Wolff AC, Hammond ME, Schwartz JN, Hagerty KL, Allred DC, Cote RJ, Dowsett M, Fitzgibbons PL, Hanna WM, Langer A, McShane LM, Paik S, Pegram MD, Perez EA, Press MF, Rhodes A, Sturgeon C, Taube SE, Tubbs R, Vance GH, van de Vijver M, Wheeler TM, Hayes DF (2007) American Society of Clinical Oncology/College of American Pathologists guideline recommendations for human epidermal growth factor receptor 2 testing in breast cancer. Arch Pathol Lab Med 131(1):18-43

37. Cheang MC, Chia SK, Voduc D, Gao D, Leung S, Snider J, Watson M, Davies S, Bernard PS, Parker JS, Perou CM, Ellis MJ, Nielsen TO (2009) Ki67 index, HER2 status, and prognosis of patients with luminal B breast cancer. J Natl Cancer Inst 101(10):736-750. doi:10.1093/jnci/djp082

38. Goldhirsch A, Wood WC, Coates AS, Gelber RD, Thurlimann B, Senn HJ (2011) Strategies for subtypes-dealing with the diversity of breast cancer: highlights of the St. Gallen International Expert Consensus on the Primary Therapy of Early Breast Cancer 2011. Ann Oncol 22(8):1736-1747. doi:10.1093/annonc/mdr304

39. Kim MJ, Ro JY, Ahn SH, Kim HH, Kim SB, Gong G (2006) Clinicopathologic significance of the basal-like subtype of breast cancer: a comparison with hormone receptor and Her2/neu- overexpressing phenotypes. Hum Pathol 37(9):1217-1226. doi:10.1016/j.humpath.2006.04.015

40. Kreike B, van Kouwenhove M, Horlings H, Weigelt B, Peterse H, Bartelink H, van de Vijver MJ (2007) Gene expression profiling and histopathological characterization of triple-negative/basallike breast carcinomas. Breast Cancer Res 9(5):R65. doi:10.1186/ bcr1771

41. Paget $S$ (1989) The distribution of secondary growths in cancer of the breast. 1889. Cancer Metastasis Rev 8(2):98-101

42. Fidler IJ (1973) Selection of successive tumour lines for metastasis. Nat New Biol 242(118):148-149

43. Langley RR, Fidler IJ (2011) The seed and soil hypothesis revisited-the role of tumor-stroma interactions in metastasis to different organs. Int J Cancer 128(11):2527-2535. doi:10.1002/ ijc.26031

44. Andry G, Suciu S, Pratola D, Sylvester R, Leclercq G, da Costa PM, Legros N, Andry-t'Hooft M, Verhest A, Mattheiem W (1989) Relation between estrogen receptor concentration and clinical and histological factors: their relative prognostic importance after radical mastectomy for primary breast cancer. Eur $\mathrm{J}$ Cancer Clin Oncol 25(2):319-329

45. Hess KR, Pusztai L, Buzdar AU, Hortobagyi GN (2003) Estrogen receptors and distinct patterns of breast cancer relapse. Breast Cancer Res Treat 78(1):105-118

46. Koenders PG, Beex LV, Langens R, Kloppenborg PW, Smals AG, Benraad TJ (1991) Steroid hormone receptor activity of primary human breast cancer and pattern of first metastasis. The Breast Cancer Study Group. Breast Cancer Res Treat 18(1):27-32

47. Raemaekers JM, Beex LV, Koenders AJ, Pieters GF, Smals AG, Benraad TJ, Kloppenborg PW (1985) Disease-free interval and estrogen receptor activity in tumor tissue of patients with primary breast cancer: analysis after long-term follow-up. Breast Cancer Res Treat 6(2):123-130

48. Winstanley J, Cooke T, Murray GD, Platt-Higgins A, George WD, Holt S, Myskov M, Spedding A, Barraclough BR, Rudland PS (1991) The long term prognostic significance of c-erbB-2 in primary breast cancer. Br J Cancer 63(3):447-450

49. Solomayer EF, Diel IJ, Meyberg GC, Gollan C, Bastert G (2000) Metastatic breast cancer: clinical course, prognosis and therapy related to the first site of metastasis. Breast Cancer Res Treat 59(3):271-278

50. Hicks DG, Short SM, Prescott NL, Tarr SM, Coleman KA, Yoder BJ, Crowe JP, Choueiri TK, Dawson AE, Budd GT, Tubbs RR, Casey G, Weil RJ (2006) Breast cancers with brain metastases are more likely to be estrogen receptor negative, express the basal cytokeratin CK5/6, and overexpress HER2 or EGFR. Am J Surg Pathol 30(9):1097-1104. doi:10.1097/01.pas.0000213306.05811. b9

51. Lobbezoo DJ, van Kampen RJ, Voogd AC, Dercksen MW, van den Berkmortel F, Smilde TJ, van de Wouw AJ, Peters FP, van Riel JM, Peters NA, de Boer M, Borm GF, Tjan-Heijnen VC (2013) Prognosis of metastatic breast cancer subtypes: the hormone receptor/HER2-positive subtype is associated with the most favorable outcome. Breast Cancer Res Treat 141(3):507-514. doi:10.1007/s10549-013-2711-y

52. Planchat E, Durando X, Abrial C, Thivat E, Mouret-Reynier MA, Ferriere JP, Pomel C, Kwiatkowski F, Chollet P, Nabholtz JM (2011) Prognostic value of initial tumor parameters after metastatic relapse. Cancer Invest 29(9):635-643. doi:10.3109/ 07357907.2011.621911

53. Rosa Mendoza ES, Moreno E, Caguioa PB (2013) Predictors of early distant metastasis in women with breast cancer. J Cancer Res Clin Oncol. doi:10.1007/s00432-012-1367-z

54. Badve S, Dabbs DJ, Schnitt SJ, Baehner FL, Decker T, Eusebi V, Fox SB, Ichihara S, Jacquemier J, Lakhani SR, Palacios J, Rakha EA, Richardson AL, Schmitt FC, Tan PH, Tse GM, Weigelt B, 
Ellis IO, Reis-Filho JS (2011) Basal-like and triple-negative breast cancers: a critical review with an emphasis on the implications for pathologists and oncologists. Mod Pathol: Off J US Can Acad Pathol, Inc 24(2):157-167. doi:10.1038/modpathol. 2010.200

55. Keam B, Im SA, Lee KH, Han SW, Oh DY, Kim JH, Lee SH, Han W, Kim DW, Kim TY, Park IA, Noh DY, Heo DS, Bang YJ (2011) Ki-67 can be used for further classification of triple negative breast cancer into two subtypes with different response and prognosis. Breast Cancer Res 13(2):R22. doi:10.1186/ bcr2834

56. Nielsen TO, Hsu FD, Jensen K, Cheang M, Karaca G, Hu Z, Hernandez-Boussard T, Livasy C, Cowan D, Dressler L, Akslen LA, Ragaz J, Gown AM, Gilks CB, van de Rijn M, Perou CM (2004) Immunohistochemical and clinical characterization of the basal-like subtype of invasive breast carcinoma. Clin Cancer Res: Off J Am Assoc Cancer Res 10(16):5367-5374. doi:10.1158/ 1078-0432.CCR-04-0220

57. Lehmann BD, Bauer JA, Chen X, Sanders ME, Chakravarthy AB, Shyr Y, Pietenpol JA (2011) Identification of human triplenegative breast cancer subtypes and preclinical models for selection of targeted therapies. J Clin Investig 121(7):2750-2767. doi:10.1172/JCI45014

58. Oka H, Shiozaki H, Kobayashi K, Inoue M, Tahara H, Kobayashi T, Takatsuka Y, Matsuyoshi N, Hirano S, Takeichi M (1993) Expression of E-cadherin cell adhesion molecules in human breast cancer tissues and its relationship to metastasis. Cancer Res 53(7):1696-1701

59. Rimm DL, Sinard JH, Morrow JS (1995) Reduced alpha-catenin and E-cadherin expression in breast cancer. Lab Invest 72(5):506-512

60. Siitonen SM, Kononen JT, Helin HJ, Rantala IS, Holli KA, Isola JJ (1996) Reduced E-cadherin expression is associated with invasiveness and unfavorable prognosis in breast cancer. Am J Clin Pathol 105(4):394-402

61. Chen WC, Obrink B (1991) Cell-cell contacts mediated by E-cadherin (uvomorulin) restrict invasive behavior of L-cells. J Cell Biol 114(2):319-327

62. Frixen UH, Behrens J, Sachs M, Eberle G, Voss B, Warda A, Lochner D, Birchmeier W (1991) E-cadherin-mediated cell-cell adhesion prevents invasiveness of human carcinoma cells. J Cell Biol 113(1):173-185

63. Mareel MM, Behrens J, Birchmeier W, De Bruyne GK, Vleminckx K, Hoogewijs A, Fiers WC, Van Roy FM (1991) Down- regulation of E-cadherin expression in Madin Darby canine kidney (MDCK) cells inside tumors of nude mice. Int $\mathrm{J}$ Cancer 47(6):922-928

64. Pierceall WE, Woodard AS, Morrow JS, Rimm D, Fearon ER (1995) Frequent alterations in E-cadherin and alpha- and betacatenin expression in human breast cancer cell lines. Oncogene 11(7):1319-1326

65. Vleminckx K, Vakaet L Jr, Mareel M, Fiers W, van Roy F (1991) Genetic manipulation of E-cadherin expression by epithelial tumor cells reveals an invasion suppressor role. Cell 66(1):107-119

66. Lipponen P, Saarelainen E, Ji H, Aaltomaa S, Syrjanen K (1994) Expression of E-cadherin (E-CD) as related to other prognostic factors and survival in breast cancer. J Pathol 174(2):101-109. doi:10.1002/path.1711740206

67. Parker C, Rampaul RS, Pinder SE, Bell JA, Wencyk PM, Blamey RW, Nicholson RI, Robertson JF (2001) E-cadherin as a prognostic indicator in primary breast cancer. $\mathrm{Br} \mathrm{J}$ Cancer 85(12):1958-1963. doi:10.1054/bjoc.2001.2178

68. Ding L, Ellis MJ, Li S, Larson DE, Chen K, Wallis JW, Harris CC, McLellan MD, Fulton RS, Fulton LL, Abbott RM, Hoog J, Dooling DJ, Koboldt DC, Schmidt H, Kalicki J, Zhang Q, Chen L, Lin L, Wendl MC, McMichael JF, Magrini VJ, Cook L, McGrath SD, Vickery TL, Appelbaum E, Deschryver K, Davies S, Guintoli T, Lin L, Crowder R, Tao Y, Snider JE, Smith SM, Dukes AF, Sanderson GE, Pohl CS, Delehaunty KD, Fronick CC, Pape KA, Reed JS, Robinson JS, Hodges JS, Schierding W, Dees ND, Shen D, Locke DP, Wiechert ME, Eldred JM, Peck JB, Oberkfell BJ, Lolofie JT, Du F, Hawkins AE, O'Laughlin MD, Bernard KE, Cunningham M, Elliott G, Mason MD, Thompson DM Jr, Ivanovich JL, Goodfellow PJ, Perou CM, Weinstock GM, Aft R, Watson M, Ley TJ, Wilson RK, Mardis ER (2010) Genome remodelling in a basal-like breast cancer metastasis and xenograft. Nature 464(7291):999-1005. doi:10.1038/nature08989

69. Piccirilli C, Saxena A, Robertson J, Clark W, Ikejiri B, Oldfield E, Ali I (1994) Allelic deletions on chromosome-17 and mutations in the p53 gene in tumors metastatic to brain. Int J Oncol 4(1):37-42

70. Lo NC, Vivenza D, Monteverde M, Lattanzio L, Gojis O, Garrone O, Comino A, Merlano M, Quinlan PR, Syed N, Purdie CA, Thompson A, Palmieri C, Crook T (2012) High frequency of complex TP53 mutations in CNS metastases from breast cancer. Br J Cancer 106(2):397-404. doi:10.1038/bjc.2011.464 